\title{
Perceived utility and limits of psychological interviews among French physicians and firefighter divers
}

\author{
Jacques Bessereau ${ }^{1,2}$, Nathalie Vital ${ }^{1}$, Valérie Guyon ${ }^{2}$, Anne Huon-Bessereau ${ }^{1}$, \\ Lionel Peteille $^{1}$, Jean-Marie Steve ${ }^{3}$, Jean-Marc Sagué ${ }^{1}$, Gaël Melot ${ }^{1}$ \\ ${ }^{1}$ SDIS du Vaucluse, Avignon, France \\ ${ }^{2}$ CUMP 13, Service de Psychiatrie, CHU La Conception, Marseille, France \\ ${ }^{3}$ SDIS des Alpes-Maritimes, Nice, France
}

Prevention of hazards is a constant preoccupation for the doctors and nurses who are in charge of ensuring, at first during the medical fitness visit (MFV), that the members of the professional firefighters are medically and psychologically fit, followed by a regular control, in particular of those carrying out specialised activities (mountaineering, scuba-diving, CBRN risks). In France, the medical conditions of the firemen's fitness who are carrying out specialized activities are statutorily set by Annex II of the Decree of 6 May 2000, recently modified on 17 January 2013 [1-3]. In addition to a certain number of specific clinical and paraclinical examinations, the firemen who carry out subaquatic activities have to undergo, among other things, a psychological interview during their MFV (initial evaluation during the recruitment and then every 4 years). It is now well established that the risk of a diving accident is increased depending on the psychological state and profile of the diver $[4,5]$. This is why the legislator has highlighted the importance of evaluating the psychological state of the diving firemen when recruited, but also in the course of their professional career.

Using first an online questionnaire for the different French Departmental Fire and Rescue Department (SDIS) and secondly a written questionnaire for the Department of Vaucluse (South of France), we wanted to know the current practices, the expectations and psychological difficulties faced by the firefighter divers during their MFV and then further on during their professional career.

Out of those 42 French SDIS who answered (42/99SDIS), 39 (97\%) have divers. Among them, 10 (26\%) underwent the psychological interview during the initial MFV and $8(21 \%)$ during the following MFVs. In those cases, initial interview was undertaken by a psychologist in
10 (56\%) cases, or by a non-specialised doctor (44\%). The subsequent interviews are also performed mainly by a psychologist $(65 \%)$, or by a non-specialised doctor (35\%). If a particular psychological problem is mentioned by one of the divers or reported by his management, it is possible to have access to a psychological interview in $100 \%$ of the 39 SDIS with divers. Finally, concerning the question about the usefulness of psychological interviews, 19 (49\%) physicians think those interviews are useful, 16 (41\%) do not exclude to have recourse to them 1 day and $3(8 \%)$ do not think they are of any use.

With regard to the SDIS of Vaucluse, we were able to analyse the data for the whole group of the firefight divers. The SDIS of Vaucluse is composed of 21 male divers, average age of 36 years (range 24-48 years). Among them, 5 (24\%) have a rather important experience of civic leisure diving since 4 of them are totally autonomous if not diving monitors. With regard to more particular activities such as dry caving, cave diving or participation to the SSF (French cave rescue system), those activities are not really related to them since 2 divers practice cave diving, another 1 practices dry caving, and none of them participates to the SSF. Out of those 21 professional divers, 3 have admitted that they had past neurological or psychiatric history: one had an accident during decompression (decompression sickness), another one had a severe trauma brain injury and the last one has been through a period of depression combined with panic attacks. Regarding their professional subaquatic activities, they all have different levels of experience; some of them started diving only 1 year ago, others have been practicing for at least 25 years, the average time being 9.5 years. During those years of practice, 9 (43\%) have experienced an incident while diving (e.g. air crash, bad decompression 
procedure, rapid ascent). During a sample year, on average they perform 5.7 real interventions and 31.2 trainings in diving. The main psychological difficulties that those divers face during their subaquatic practice, are mainly linked to the difficult conditions due to turbidity of the water, its temperature and the water flow (62\%), to their apprehension of what they are going to find under water (48\%), rarely to the fact that they have to dive "in emergency", without previous preparation (24\%); and exceptionally linked to the memory of a prior anxiety-producing situation (5\%).

Nevertheless, through this study we realised that the psychological dimension of the firefight diving is not of interest to all the specialists of this profession: only one quarter (26\%) of the French SDIS have put in place a psychological evaluation of their divers when recruited for this job. Half of firefight divers (48\%) themselves don't see any interest in such an evaluation.

Even though statutory (Decree of 6 May 200 modified on 17 January 2013), the psychological evaluation is not systematically proposed to the diving firemen. It is nevertheless admitted that psychological disturbances, chronic or transitory (anxiety, compulsive obsessional disturbances, depression) may cause diving accidents. There is still work to be done to persuade those divers of this facility, but also and mainly to persuade the firefighter doctors in charge of this category of professionals.

\section{ACKNOWLEDGEMENTS}

We would like to thank Annie Guyon for her help in English translation of the text.

\section{REFERENCES}

1. French Law: Arrêté du 6 mai 2000 modifié fixant les conditions d'aptitude médicale des SPP et SPV et les conditions d'exercice de la médecine professionnelle et préventive au sein des SDIS. JO Lois et décrets du 11 juin 2000, p. 8869.

2. French Law: Annexe II relative aux conditions d'aptitude médicale auxquelles doivent satisfaire les sapeurs-pompiers pratiquant des activités spécialisées.

3. French Law: Arrêté du 17 janvier 2013 modifiant l'arrêté du 6 mai 2000 fixant les conditions d'aptitude médicale des SPP et SPV et les conditions d'exercice de la médecine professionnelle et préventive au sein des SDIS. JO Lois et décrets du 25 janvier 2013, NOR: INTE1301513A.

4. Gempp E, Louge P, Blatteau JE, Hugon M. Risks factors for recurrent neurological decompression sickness in recreational divers. A case-control study. J Sports Med Phys Fitness 2012; 52: 530-536.

5. Bessereau J, Genotelle N, Brun PM et al. Decompression sickness in urban divers in France. Int Marit Health 2012; 63: 170-173. 